\section{Global EnERGY CONSUMPTION}

\author{
JANA LIPPELT AND \\ MAXIMILIAN SINDRAM*
}

In recent years, primary energy consumption in the world constantly increased. Since the Second World War it rose to a current level (2009) of 131 million gigawatt hours. This trend was only interrupted by a slight decrease from 1979 to 1982 , which was due to the second oil crisis. In 2008, the worldwide recession led to another decrease, particularly observed in the United States ( 5.0 percent), the European Union ( -5.6 percent) and Russia ( -6.4 percent). In China, however, consumption increased by 8.7 percent. Generally, a decline by 1.1 percent was noticed throughout the world. This article gives a short overview of the primary and final energy consumption and the related global connections.

First, it is necessary to differentiate between primary and final energy. Primary energy describes the energy stored in fossil energy sources like oil, coal and gas. In addition to that there is energy from uranium and biomass as well as energy from physical processes driven by solar radiation, wind and hydraulic power. In contrast, final energy is energy actually available to the final consumer. The flow from energy production to its consumption is displayed by energy balances that show the quantity, transformation and consumption of energy in a country or economic area are shown during a certain period (see AG Energiebilanzen 2010). They provide information about both the amount and structure of energy consumption, the share of imported and exported energy as well as consumption patterns and conversion losses. They also constitute the basis for determining $\mathrm{CO}_{2}$ emissions. Generally, energy balances are a prerequisite for economic and energy policy decisions and forecasts.

The global primary energy consumption per capita is shown in the first map of Figure 1. It reflects the con-

* Ifo Institute for Economic Research. sumer demand for energy, which depends on a country's stage of development and the energy awareness of the people. Among the countries with the highest energy consumption per capita are the countries of the Arab Peninsula, Scandinavian countries and industrialized countries such as the United States, Canada or Australia. China only is in the middle of the per capita consumption since large parts of the country are not industrialized, while its total energy consumption is in second place worldwide, after the United States. The map below shows the share of final energy consumption in primary energy supply, which varies globally from 100 percent to 40 percent, with Luxembourg on the top. Germany is highly-ranked with a share of 70 percent, whereas Qatar, compared to high final energy consumption per capita, has a relatively small share of final demand (IEA 2010). Rising final energy consumption per capita leads to a declining share of consumed final energy in primary energy. This is especially apparent in countries that export most of their primary energy such as Qatar, United Arab Emirates and Kuwait.

High energy consumption per capita does not necessarily mean that a country consumes much of the energy resources. Iceland, for example, possesses a sufficient amount of energy from hot springs and water power, so that only 30 percent of its primary energy needs to be imported from fossil fuels. Consequently, energy costs are very low compared to world standards. This provides incentives to shift energy-intensive processing of raw materials to Iceland. As a result, the primary energy consumption (and thus the statistical per capita consumption) is high without Icelandic consumers being responsible for this.

In order to limit the consumption of energy, many countries already have established different regulations. Since a majority of energy consumption takes place in buildings (in Germany up to 40 percent), regulations are often introduced in this sector. In Germany, the Energy Conservation Act was passed in 2002, requiring minimum technical standards for old and new buildings. This new method of determining thresholds of energy consumption affects 
Figure 1

\section{Primary Energy}
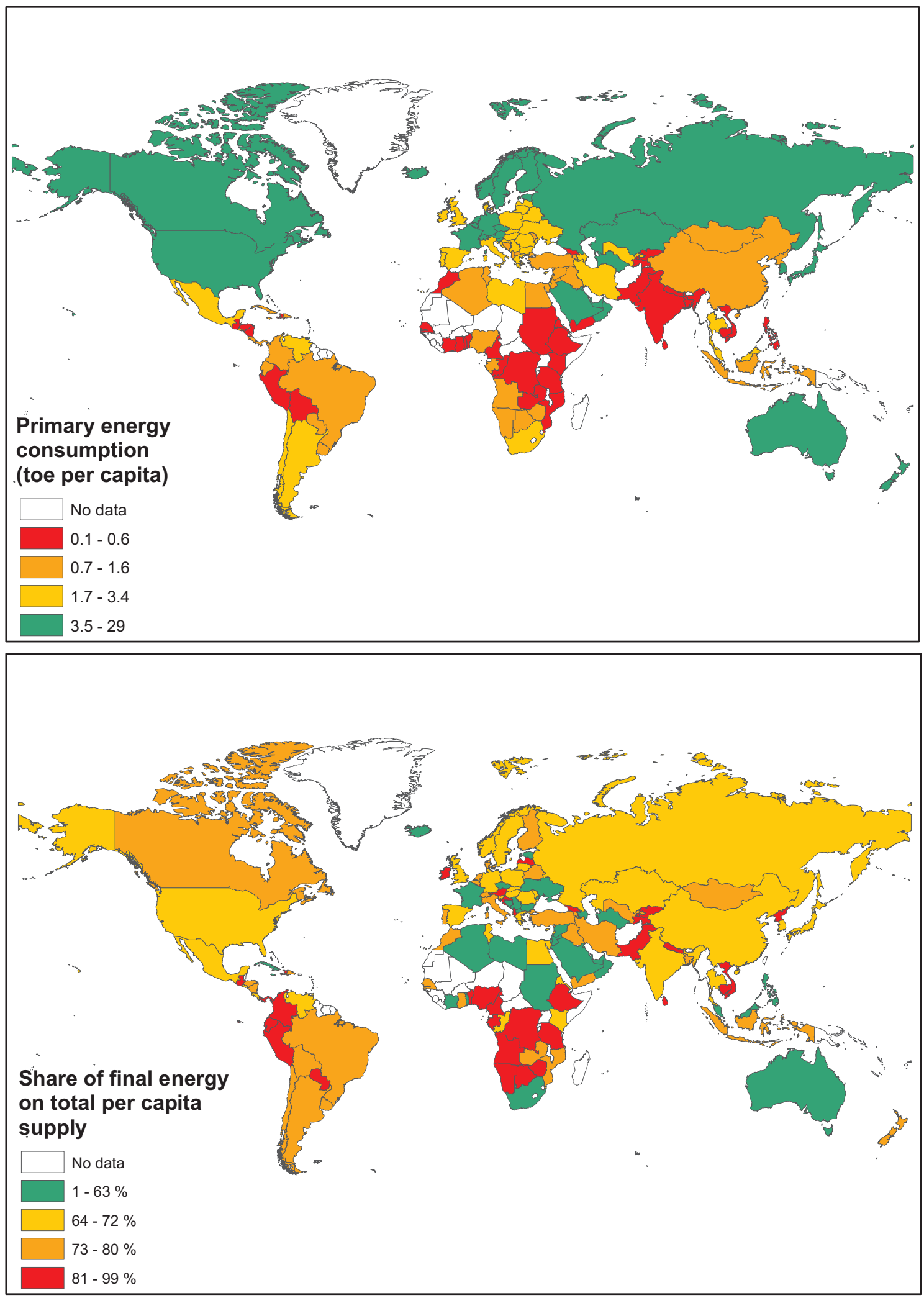

Source: IEA (2010). 
existing buildings as well as new buildings. Rather than defining a maximum annual heating demand and minimum thermal insulation for plant-specific heat protection, the new rules relate to the annual primary energy demand. Besides the heating demand this measure also includes the amount of energy used for heating water. Regulations also concern the energy consumption of cars and the energy efficiency of the industrial sector. In 2009, a new system of a combined $\mathrm{CO}_{2}$ and cubic capacity related taxation of cars was enacted in Germany. In addition to the capacity and the type of engine, the tax rate is defined by the amount of $\mathrm{CO}_{2}$ emissions (Umweltbundesamt 2009).

The United States held the top position of worldwide total energy consumption in 2008 with a share of 20 percent and had thereby overtaken China (BP 2010). Interestingly, 25 percent of the world's population, mainly located on the northern hemisphere, uses 75 percent of the available primary energy (KatalyseInstitut 2011). Against the background of rising global energy demand, it is essential to further discuss approaches for the regulation, conservation and distribution of energy consumption on a regional as well as global scale.

\section{References}

AG Energiebilanzen (2010), Vorwort zu den Energiebilanzen für die Bundesrepublik Deutschland, http://www.ag-energiebilanzen.de/viewpage.php?idpage $=5$.

BP (2010), Review of World Energy 2010, http://www.bp.com/liveassets/bp internet/globalbp/globalbp uk english/reports and publications/statistical_energy_review_2008/STAGING/local_assets/2010 _downloads/Statistical_Review_of_World_Energy_2010.xls..

International Energy Agency (IEA, 2010), Data Services Database, http://data.iea.org/ieastore/default.asp?

Katalyse - Institut für angewandte Umweltforschung (2011), Energie, http://www.umweltlexikon-online.de/RUBenergie/Energie.php.

Umweltbundesamt (2009), Kraftstoffverbrauch, http://www.umweltbundesamt-daten-zur-umwelt.de/umweltdaten/public/theme.do? nodeIdent $=2330$. 